\title{
Relationship of Anemia in Pregnancy with Postpartum Hemorrhage in Jombang Regional Hospital
}

\author{
Farah Luthfia Nugroho 1, Ninuk Dwi Ariningtyas 2, Yudith Annisa Ayu Rezkita 3, Pribakti \\ Budinurdjaja ${ }^{4}$, Muhammad Anas 2 * \\ ${ }^{1}$ Student of Medical Faculty of University Muhammadiyah of Surabaya 60113, Indonesia \\ ${ }^{2}$ Department of Obstetric Gynecologic, Medical Faculty of University Muhammadiyah of Surabaya 60133, \\ Indonesia \\ ${ }^{3}$ Department of Internal Medicine, Medical Faculty of University Muhammadiyah of Surabaya 60133, In- \\ donesia \\ 4 Department of Obstetric Gynecologic, Medical Faculty of University Lambung Mangkurat, Banjarmasin, \\ 70122, Indonesia
}

Article history:

Submission March 2020

Revised April 2020

Accepted May 2020

*Corresponding author:

E-mail:

muhanasjamil1@yahoo.co.id

\begin{abstract}
Introduction: Based on the Health Profile of East Java Province it was noted that the maternal mortality rate is still high, with the highest cause of maternal death being preeclampsia/eclampsia which is $28.92 \%$, and hemorrhage by $26.28 \%$. Mothers with anemia have a higher risk of postpartum hemorrhage. This is caused by the lack of oxygen and nutrients in the uterine organs, resulting in a decrease in myometrium muscle contraction that causes hemorrhage. Objective: To determine the relationship between anemia in pregnancy and postpartum hemorrhage in Jombang Regional Hospital 20162019. Method: Researchers use analytic research with a case-control approach. The study population of women who experienced hemorrhage at Jombang Regional Hospital in 2016-2019 (as a case group population). And women who did not experience hemorrhage at Jombang Regional Hospital in 2016-2019 (as a control group population). The sample of each study was 36 respondents for the case and control groups with a non-probability sampling technique consecutive sampling, and a matching process was carried out. Results: The significance value in the Mann Whitney test was $0.000(\mathrm{p}<0.05)$, which means that $\mathrm{HO}$ was rejected, there was a significant relationship between anemia in pregnancy and postpartum hemorrhage in Jombang Regional Hospital. As well as the strength of the relationship between anemia and postpartum hemorrhage which was calculated using the Contingency Coefficient test. shows a figure of 0.582 , which shows a positive correlation with sufficient strength correlation. Conclusion: Based on the results of research that has been done shows that there is a relationship between anemia in pregnancy with postpartum hemorrhage in Jombang Regional Hospital 20162019.
\end{abstract}

Keywords: Anemia, postpartum-hemorrhage, pregnancy, retention of placenta, antonia

\section{Introduction}

The health profile of East Java Province (2017) [1] noted that the maternal mortality rate was still high, with the highest cause of maternal death being preeclampsia/eclampsia which was $28.92 \%$, and hemorrhage of $26.28 \%$, while the smallest cause was an infection of $3,59 \%$. It is estimated that $41.8 \%$ of pregnant women around the world experience anemia, at least half of that number is caused by iron deficiency. Pregnant women are said to be anemic if the hemoglobin level is less than 11 $\mathrm{mg} / \mathrm{L}$, this condition is associated with increased premature birth, maternal and child mortality, and infectious diseases [2].

In one study it was found that hemoglobin concentrations were consistent with increasing gestational age. In the early trimester seems to

\section{How to cite:}

Nugroho FL, Ariningtyas ND, Rezkita YAA, Budinurdjaja P, Anas M (2020) Relationship of anemia in pregnancy with postpartum hemorrhage in Jombang Regional Hospital. Indonesian Journal of Medical Sciences and Public Health 1 
decrease, but in the second trimester, around 30 weeks of gestational age is where the hemoglobin concentration occurs lowest and in the third-trimester increase in hemoglobin [3]. Mothers with anemia have a risk of postpartum hemorrhage mainly due to inadequate contraction of the myometrium muscle. That is because of the reduction in red blood cells in the blood that is unable to meet oxygen throughout the body's tissues so that the needs of the tissues in the body are not met [4].

Based on the description above, the authors are interested in researching with the title "Relationship of Anemia in Pregnancy with Postpartum Hemorrhage in Jombang Regional Hospital". This research is planned to be conducted at Jombang Regional Hospital because previously there had never been any research on the relationship of anemia with postpartum hemorrhage.

\section{Material and Methods}

The research design used was observational analytic with a retrospective approach and a case-control study design. The variables used in this study are the dependent variable, Postpartum Hemorrhage, and the independent variable, anemia in pregnancy. The population in this study maternity patient who experienced hemorrhage in Jombang Regional Hospital in 2016-2019 (as a case group population). And women who did not experience hemorrhage at Jombang Regional Hospital in 20162019 (as a control group population). With non-probability sampling technique consecutive sampling. To get good control, the researcher did a matching, which is choosing a control with the same characteristics as the case in all variables that might act as risk factors except the variables studied [5]. The variables used for the matching process are the age and parity of the patient. The large sample formula to be used Is [5]:

$$
\mathbf{n}_{1}=\mathbf{n}_{2}=\frac{\left(\mathrm{Z} \boldsymbol{\alpha} \sqrt{2 \mathrm{PQ}}+\mathrm{Z} \boldsymbol{\beta} \sqrt{\mathrm{P}_{1} \mathrm{Q}_{1}+\mathrm{P}_{2} \mathrm{Q}_{2}}\right)^{2}}{(\mathrm{P} 1-\mathrm{P} 2)^{2}}
$$

The $Z \alpha$ used is $1,96, Z \beta$ is $0,842, O R$ is 5 , the estimated proportion of effects on controls $\left(\mathrm{P}_{2}\right)$ is 0,275 [6], the sample size used by researchers was 36, with a case and control ratio of $1: 1$, so the total sample used was 72 . Analysis of the data used in univariate analysis and bivariate analysis. Univariate analysis to assess the distribution and normality of data from the collected variables, and bivariate analysis to assess the relationship between two variables, these two variables are anemia in pregnancy with postpartum hemorrhage.

The statistical analysis technique used is the Mann Whitney test. The comparative test results are interpreted using a $4 \times 2$ table, and the correlation coefficient is calculated using the Gamma correlation test to determine the value of the correlation coefficient. Interpretation of $p$ values with confidence intervals ie $p$ values $>0.05$ shows no significant correlation, and $\mathrm{p}$ values $<0.05$ indicate a significant correlation. As well as the correlation coefficient to determine the strength of the correlation that is getting closer to 1 , the strength of the statistical correlation is getting stronger [7].

\section{Results and Discussion Distribution of Patient Age}

This study was conducted using data on spontaneous delivery in Jombang Regional Hospital 2016-2019, who experienced hemorrhage and did not experience hemorrhage.

In the matching process that is choosing a control with the same characteristics as the case in all variables that might act as risk factors except the variables studied [5].

It was found that the most maternal age group with hemorrhage (case group) occurred in patients $>31$ year's old as many as 17 patients $(47.2 \%)$ while in the maternal group who did not experience postpartum hemorrhage (control group) the most occurred in patients $\leq 25$ year's old as many as 17 people (47.2\%). In the study, age is used as a variable for the matching process, because age is not the main cause of the incidence of postpartum hemorrhage, but only as a predisposing factor. This is concluded from the results of the chi-square test conducted between age and hemorrhage events, obtained a significance value of $0.027 \mathrm{c} p$ $>0.005$ ) which means there is no meaningful relationship between age and postpartum 
hemorrhage. This is in line with research by Pitriani, R. that at the age of over 35 years a woman's reproductive function has decreased compared to normal function so that the possibility for postpartum complications especially hemorrhage will be greater. Anemia affects the workings of each organ of the human body because the amount of oxygen bound in the blood is less, if it occurs in pregnant women then it will further affect the work of the uterine muscles to contract during labor and cause postpartum hemorrhage [8].

\section{Distribution of Patient Parity}

The parity on this study that was conducted using data on spontaneous delivery in Jombang Regional Hospital 2016-2019, who experienced hemorrhage and did not experience hemorrhage, listed at table 2. Significance results obtained using the chi-square test that is $0.628(p<0.005)$ which means there is no significant relationship between parity with the incidence of postpartum hemorrhage. Therefore, researchers only set parity as a variable in the matching process. As with age, which only predisposes to postpartum hemorrhage.

Since parity is a variable in the matching process in this study, the results obtained are also in line with research by Ummah et al., [9] where patients in the case group of mothers who already had 2-3 children before as many as 20 patients (55.5\%) experienced hemorrhage, and in the control group of mothers who had not had 1 child before as many as 17 patients $(47.3 \%)$ did not experience hemorrhage.
Wiknjosastro in Yogi et al. [10] tell that a woman who has experienced pregnancy 6 times or more, will have the opportunity to experience weak contractions during labor, hemorrhage after childbirth (due to weakened uterine muscles), therefore higher parity, higher risk of maternal death. Because during pregnancy the uterus experiences enlargement, which is followed by stretching of the muscles of the uterus. As a result of this stretch elasticity of the muscles of the uterus can not return before pregnancy. So the more often the mother gets pregnant and gives birth, the closer the distance of pregnancy and birth, the elasticity of the uterus is also increasingly disrupted, as a result, the uterus cannot contract completely and results in postpartum hemorrhage [9].

\section{Distribution of Cause of Postpartum Hemor- rhage}

The distribution of causes of postpartum hemorrhage in Jombang Regional Hospital in 2016-2019 in 49 patients obtained retention placenta 33 patients $(67.3 \%)$, laceration of the birth canal 3 patients $(6.12 \%)$, preeclampsia one patient $(2.04 \%)$, atonia uteri 3 patients (6.12\%), perineum rupture grade 4 one patient (2.04\%), placental retention and laceration of the birth canal for 6 patients (12.25\%), placenta retention and preeclampsia one patient (2.04\%), and placenta retention and perineum rupture grade 4 one patient $(2.04 \%)$.

Table 1. Patient Age Distribution

\begin{tabular}{|c|c|c|c|c|}
\hline \multirow{2}{*}{$\begin{array}{c}\text { Age } \\
\text { (year old) }\end{array}$} & \multicolumn{2}{|c|}{ Hemorrhage } & \multicolumn{2}{|c|}{ No Hemorrhage } \\
\hline & Sum & $\%$ & Sum & $\%$ \\
\hline$\leq 25$ & 10 & $27,8 \%$ & 17 & $47,2 \%$ \\
\hline $26-30$ & 9 & $25,0 \%$ & 11 & $30,6 \%$ \\
\hline$>31$ & 17 & $47,2 \%$ & 8 & $22,2 \%$ \\
\hline Total & 36 & $100,0 \%$ & 36 & $100,0 \%$ \\
\hline
\end{tabular}

Table 2. Distribution of Patient Parity

\begin{tabular}{|c|c|c|c|c|}
\hline \multirow{2}{*}{ Parity } & \multicolumn{2}{|c|}{ Hemorrhage } & \multicolumn{2}{|c|}{ No Hemorrhage } \\
\hline & Sum & $\%$ & Sum & $\%$ \\
\hline 0-1 & 11 & $30,6 \%$ & 17 & $47,3 \%$ \\
\hline $2-3$ & 20 & $55,5 \%$ & 11 & $30,5 \%$ \\
\hline$>3$ & 5 & $13,9 \%$ & 8 & $22,2 \%$ \\
\hline Total & 36 & $100,0 \%$ & 36 & $100,0 \%$ \\
\hline
\end{tabular}


Table 3 Distribution of Causes for Patient Hemorrhage

\begin{tabular}{|c|c|c|}
\hline Cause of Hemorrhage & Sum & Percentage \\
\hline Placental retension & 33 & $67,35 \%$ \\
\hline Lacerations of the birth canal & 3 & $6,12 \%$ \\
\hline Preeclamsia & 1 & $2,04 \%$ \\
\hline Atonia Uteri & 3 & $6,12 \%$ \\
\hline Grade 4 Perineum Rupture & 1 & $2,04 \%$ \\
\hline Placental retention and Lacerations of the birth canal & 6 & $12,25 \%$ \\
\hline Placental retension and Preeclamsia & 1 & $2,04 \%$ \\
\hline Placental retension and Perineum rupture grade 4 & 1 & $2,04 \%$ \\
\hline
\end{tabular}

Table 4 Relationship Anemia with Postpartum Hemorrhage

\begin{tabular}{lcccccc}
\hline \multicolumn{1}{c}{ Anemia } & \multicolumn{2}{c}{ Hemorrhage } & \multicolumn{2}{c}{ No Hemorrhage } & $\boldsymbol{p}$ & Coeff. Correl \\
\hline & Sum & $\%$ & Sum & $\%$ & & \\
\hline No Anemia & 5 & $13,9 \%$ & 11 & $30,6 \%$ & & 0,582 \\
\hline Mild & 2 & $5,5 \%$ & 21 & $58,3 \%$ & \multirow{2}{*}{0,000} & $8,3 \%$ \\
\cline { 1 - 5 } Moderate & 24 & $66,7 \%$ & 3 & & $2,8 \%$ \\
\hline Severe & 5 & $13,9 \%$ & 1 & & \\
\hline
\end{tabular}

Then patients with causes other than placental retention and uterine atony were eliminated using exclusion criteria made by the investigators.

It can be interpreted that the majority of cases of postpartum hemorrhage in Jombang Regional Hospital 2016-2019 are retained placenta. Of the total sample 36 patients in the case group, 33 patients experienced postpartum hemorrhage due to placental retention and 3 other patients were caused by uterine atony.

The results of this study are in line with the theory that the lower the Haemoglobin level, the greater the risk for postpartum hemorrhage, especially placental retention, in a study by Permatasari obtained a significant relationship between placental adhesions (placental retention) with educational variables ( $\mathrm{p}$-value 0.003 ) and also anemia status ( $p$-value 0.049 ) [11].

\section{The Relationship of Anemia in Pregnancy with Postpartum Hemorrhage}

The results of the table in the Mann Whitney test conducted in the study showed that patients with moderate or severe anemia were prone to hemorrhage. While patients with mild anemia and no anemia, the majority did not experience hemorrhage. The significance value in the Mann Whitney test was $0,000(p<0.05)$, which means that $\mathrm{H} 0$ was rejected, there was a significant relationship between anemia in pregnancy and postpartum hemorrhage in Jombang Regional Hospital in 2016-2019. As well as the strength of the relationship of anemia with postpartum hemorrhage calculated using the Contingency Coefficient test showed a figure of 0.528 which shows a positive correlation with the strength of a strong correlation.

The results of this study are in line with Lestari's [12] research on the analysis of the relationship of anemia with postpartum hemorrhage in General Ahmad Yani Hospital Metro City. The results showed that the variable associated with the incidence of postpartum hemorrhage was anemia in obtaining a value of $p=$ $0,000(\mathrm{OR}=5,313)$. Postpartum hemorrhage can be caused by direct and indirect causes, according to Oxorn in Lestari, the direct causes of postpartum hemorrhage are uterine atony, placental retention, trauma, and coagulation disorders. Besides these factors, other predisposing factors are maternal age, parity, birth spacing, and anemia [12].

Aryani also conducted a similar study regarding the relationship of anemia during pregnancy with the incidence of postpartum hemorrhage in Panembahan Senopati Hospital Bantul. The results in the group of cases of pregnant women with anemia that occurred postpartum hemorrhage as many as $39(30.5 \%)$ in the control group of pregnant women with anemia who did not postpartum hemorrhage as 
many as $15(11.7 \%)$. The $p$-value is $0,000<0.05$ which means that there is a relationship between anemia during pregnancy and postpartum hemorrhage with an Odds Ratio (OR) of 5.096 [13]. Aryani in her research stated that when a mother gives birth there will be an adequate uterine contraction so that the baby can be born, if the mother has anemia during pregnancy then the uterine contractions will decrease this is due to lack of oxygen and nutrients in the uterine organs if the uterus is lacking oxygen and nutrition, the uterine cells will experience a decrease in the form of a decrease in contractions, this decrease in contractions will cause hemorrhage [13].

This study shows patients in the group of cases with moderate to severe anemia who experience hemorrhage, whereas in the control group of patients who do not experience hemorrhage the majority are patients without anemia to mild anemia. So, the higher the level of maternal anemia, the greater the chance of hemorrhage. This is similar to the study of the effect of anemia levels on postpartum hemorrhage conducted by Siagian [14]. The level of anemia and the incidence of postpartum hemorrhage have a significant relationship ( $p$ $<0.05$ ). Especially moderate to severe anemia which has a significant relationship with postpartum hemorrhage, because severe anemia can reduce the strength of the uterine muscle or make the mother more vulnerable to infectious diseases so that severe anemia can cause postpartum hemorrhage and even death [14].

Even mild anemia can increase the levels of nitric oxide (NO) and improve its biological effects, which in turn can result in uterine muscle relaxation and atonic postpartum hemorrhage. Such complications could be prevented by avoiding or treating anemia during pregnancy [15]. Nitric oxide development response to oxidative stress of anemia has different characteristics and effects with inhaled nitric oxide, which have a specific effect on the smooth muscle of the pulmonary vasculature [16].

Some substances such as nitrites, organic nitrates, nitroso compounds, and nitric oxidecontaining substances can activate guanylyl cyclase and increase the synthesis of cyclic guanosine-3',5'-monophosphate (cGMP) in smooth muscle and other tissues. The cGMP compound, which is based on protein kinase, is stimulated by results that influence the phosphorylation of different proteins in the smooth muscle. That causes MLC (light chain myosin) dephosphorylation. The stability of smooth muscle contraction is regulated by MLC phosphorylation [17].

\section{Conclusion}

Most patients in Jombang Regional Hospital 2016-2019 who undergo postpartum hemorrhage are caused by placental retention. A total of 72 pregnant women with anemia who were chosen as study samples had mild anemia, compared to 27 cases. A total of 72 pregnant women with anemia were chosen as test subjects, 36 of whom had hemorrhaged. The majority of those who have hemorrhage are 24 pregnant patients with mild anemia. There is a significant relationship between anemia in pregnancy and the occurrence of postpartum hemorrhage.

\section{Acknowledgment}

Thank you to Director of Jombang Regional General Hospital for providing the opportunity to research on Medical Report Department of the hospital.

\section{References}

1. Dinas Kesehatan Propinsi JawaTimur (2017) East Java Province Health Profile 2017. Vol. 34, Nucleic Acids Research. Surabaya, Dinkes Jawa Timur, 77-77 p.

2. Dinas Kesehatan Republik Indonesia (2013) Basic Health Research. Diabetes Mellitus. Jakarta, Kemenkes RI, 87-90 p.

3. Prawiroharjo S (2011) Ilmu Kebidanan. 3rd ed. Jakarta, Yayasan Bina Pustaka Sarwono, 775-80 p.

4. Utami W, Setiyaningsih R (2017) Relationship between Anemia during Pregnancy and Postpartum Hemorrhage in Permata Bunda Hospital Puwodadi.

5. Sastroasmoro S, Ismael S (1995) Dasar-Dasar Metodologi Penelitian Klinis. 5th ed. Jakarta, Sagung Seto, 146-54, 368$71 \mathrm{p}$.

6. Satriyandari Y, Hariyati NR (2017) Factors That influence postpartum bleeding occurrence. J Heal Stud. 1(2):49-64.

7. Dahlan MS (2011) Statistik Untuk Kedokteran dan Kesehatan : Deskriptif, Bivariat, dan Multivariat, Dilengkapi dengan Aplikasi Menggunakan SPSS. Jakarta, Epidemiologi Indonesia, $302 \mathrm{p}$. 
8. Pitriani R (2017) Factors related to post partum hemorrhage event in Camar II Room RSUD Arifin Achmad Riau Province 2016. MENARA Ilmu XI(1):243-55.

9. Ummah N, Ulfiana E (2018) Risk factors for postpartum bleeding. J KEBIDANAN 7(15): 1-9.

10. Yogi ED, Setiawan SA, Hastuti SD, Yogi ED (2018) Relationship between Parity and Occurrence of Bleeding in Post Partum Mothers at BPS Ny. N In the Serut Klagen Village, Jiwan District, Madiun. J Delima Harapan 5(2):29-34.

11. Permatasari, Handayani R (2017) Factors Related to the Occurrence of Placental Adhesions (Retensio Placenta). ARKESMAS 2 (1) :102-8. Available from: https://iournal.uhamka.ac.id/index.php/arkesmas/article/ view $/ 512$

12. Studi P, Metro K, Kemenkes P (2014) Relationship Analysis of Anemia with Postpartum Hemorrhage in General Hospital Ahmad Yani Metro City 2013. Jurnal Kesehat Metro Sai Wawai VII (2): 1-10.

13. Aryani F (2017) Relationship between anemia during pregnancy and postpartum hemorrhage event in
Panembahan Senopati Hospital Bantul [Internet]. FIK Univesitas Aisyiyah. Available from: http://digilib.unisayogya.ac.id/2710/.

14. Siagian R, Sari RDP, S PRA (2017) Relationship between Parity Level and Anemia Rate with Postpartum Hemorrhage Occurrence in Maternity Women. J Major 6(3):45-50. Available from: http://juke.kedokteran.unila.ac.id/index.php/majority/arti cle/view/1107/954

15. Soltan MH, Ibrahim EM, Tawfek M, Hassan H, Farag F (2012) Raised nitric oxide levels may cause atonic postpartum hemorrhage in women with anemia during pregnancy. Int J Gynecol Obstet 116(2):143-7. doi.org/10.1016/j.ijgo.2011.09.017

16. Anas M, Triastuti N, Airlangga MP (2020) Role of Inhaled Nitric Oxides in Pregnancy with Eisenmenger Syndrome. QANUN Med 4(1):11-26.

17. Anas M, Marlina U (2018) Penggunaan Nitrovasodilator Sebagai Donor Oksida Nitrik Pada Preeklamsia. In: Proceeding Annual Meeting APKKM Ke 6 Surabaya, p. 1-27. 